\title{
From essence to Lebenswelt as a method in phenomenological psychopathology
}

\author{
Das essências ao Lebenswelt como método \\ em psicopatologia fenomenológica
}

Virginia MOREIRA ${ }^{1}$

\begin{abstract}
The use of different phenomenological philosophies as a methodological inspiration in psychopathology certainly leads to methodological implications that must be taken into account. Karl Jaspers, who was inspired by Husserl's transcendental phenomenology, sought the essence so as to reach the generality of the lived psychopathology, thereby giving birth to general psychopathology. This paper advocates for the ambiguous phenomenological method, inspired by Merleau-Ponty's philosophy of ambiguity, as a means to describe the lived psychopathology as Lebenswelt at the intersection of singular and universal in the reversibility of the chiasm. By leaving aside the essence and turning to the Lebenswelt, the ambiguous phenomenological method assumes that the lived pathology is produced in the intersection between the world and man, with culture as a constitutive dimension.
\end{abstract}

Keywords: Lebenswelt; Merleau-Ponty; Method; Phenomenological psychopathology.

\section{Resumo}

A utilização de diferentes fenomenologias filosóficas como inspiração metodológica em psicopatologia traz implicações metodológicas que devem ser levadas em conta. Karl Jaspers, que se inspirou na fenomenologia transcendental de Husserl, buscou as essências para alcançar a generalidade do vivido psicopatológico, criando a psicopatologia geral. Esse artigo propõe o método fenomenológico ambíguo, inspirado na fenomenologia da ambiguidade de Merleau-Ponty, para descrever o vivido psicopatológico como Lebenswelt, na interseção do singular com o universal, na reversibilidade do quiasma. Deixando de lado as essências e voltando-se para o Lebenswelt, o método fenomenológico ambíguo assume que o vivido psicopatológico se produz na interseção homem e mundo, tendo a cultura como dimensão constitutiva.

Palavras-chave: Lebenswelt; Merleau-Ponty; Método; Psicopatologia fenomenológica.

Phenomenology (from the Greek word phainesthai: that which is shown or presented, plus logos: explanation, study), as we understand it today, was initially conceived by Edmund Husserl (1859-1938) in the late 1890s as a new method for philosophical inquiry, namely an attempt to

\footnotetext{
1 Universidade de Fortaleza, Programa de Pós-Graduação em Psicologia, APHETO - Laboratório de Psicopatologia e Clínica Humanista Fenomenológica. Av. Washington Soares, 1321, 60811-905, Fortaleza, CE, Brasil. E-mail: <virginiamoreira@unifor.br>.
} 
approximate abstract metaphysical speculations to real problems, that is, to the life of experience and facts. Husserl's philosophical phenomenology was later interpreted by his followers, famous names such as Heidegger, Sartre and Merleau-Ponty, as an existential phenomenology, becoming one of the strongest philosophical trends in the $20^{\text {th }}$ century (Moreira, 2004, 2009a, 2011a; Moran \& Mooney, 2002; Moreira \& Sloan, 2002).

In former studies I have questioned, bearing in mind the different sorts of spokesmen for phenomenological thinking in philosophy, the validity of calling for a single phenomenological method of research in psychopathology, without taking into consideration the aspects and subtleties of different phenomenologies from each of the school's foremost authors. For instance, the phenomenology of Husserl, its founder, in its transcendental idealism; or the existential phenomenology of Heidegger, with its ontology of the being-in-the-world; the anthropologicallyoriented and ambiguous existential phenomenology of Merleau-Ponty, all have distinguishing philosophical aspects from one another, nevertheless, they are all philosophical phenomenologies. To behold specific philosophies so as to inspire one's own research methods in psychopathology, psychology and psychiatry certainly leads to methodological implications that must be taken into account (Moreira, 2004, 2009a).

The use of phenomenology in clinics, i.e., clinical phenomenology, which includes psychopathology, psychotherapy, psychiatry and clinical psychology, is different from philosophy itself, even though it is inspired by it (Tatossian, 1979/2006; Tatossian \& Moreira, 2012). This begins in the early 1900s, not as the trivial use of theoretical philosophy in psychiatry, psychology or psychopathology clinics, but rather as a way of questioning and trying to understand the mentally ill. Still, the lack of clear boundaries between these two areas, philosophy and clinics, causes misunderstandings and induces inaccurate clinical practices (Tatossian \& Moreira, 2012; Tatossian \& Samuelian, 1979/2006). According to Tatossian (1979/2006), the relationship between philosophical and clinical phenomenologies - the author is actually referring to psychiatry and psychopathology but we may include clinical psychology and psychotherapy as well -, must be one of implication, not of application. A relationship of implication between philosophical and clinical phenomenologies translates as the establishment of a structuring basis allowing a particular view of experience, which should be a place of disquiet and questioning, inspired by a certain kind of philosophical phenomenology in order to reflect phenomenologically on the clinic and the lived psychopathology.

In historical terms, we may set the birthdate of phenomenological psychopathology in 1922, during the $63^{\text {th }}$ meeting of the Swiss Society for Psychiatry in Zurich, when Minkowski and Binswanger presented their studies on melancholy and schizophrenia based on phenomenological perspectives (Tatossian, 1985/1997, 1979/2006). But phenomenology had already been applied to psychiatry before, namely by Karl Jaspers who, concerned with the psychiatric perspective of his time (which was restricted to natural activity and observable symptoms), had read the philosophical works of Edmund Husserl (1859-1938).

Jaspers was inspired by Husserl's early transcendental phenomenology, a method for seeking the essence and thereby aiming at the generality of the lived psychopathology. However, in his last work "The Crisis of European Sciences and Transcendental Philosophy" Husserl (1936/ 1970) expanded his idea of the world as a horizon, and of the analysis of the world of life or lived world, the Lebenswelt, which is insolubly connected to and deeply rooted in human experience. While Husserl's transcendental thought - the pursuit of a pure method capable of probing into the essence of pure conscience -, remains until the last of his oeuvre, he adjusts, in his later writings, the object of phenomenology, from the transcendental ego to Lebenswelt. Husserl (1936/1970) defines the Lebenswelt as "the common ground of human life" (p.176), "the world in which we live through intuition, with its real entities, as far as they are given to us, at first in simple experience..." (p.177). 
This idea reappears in the work of the French philosopher Maurice Merleau-Ponty (1908-1961) who resumes quite straightforwardly, by way of an existentialist interpretation of the Husserl's later phenomenology, Husserl's philosophical project, devising therefrom a philosophy of ambiguity that takes the concept of Lebenswelt as its guiding principle (Bidney, 1989; Moreira, 2007a, 2009a). In "The Phenomenology of Perception", MerleauPonty (1945) states that phenomenology is "a philosophy which puts essence back into existence, and does not expect to arrive at an understanding of man and the world from any starting point than that of their 'facticity'" (p.1). On worldliness, which, in a pre-reflexive level, is inherent to us, and which characterizes the Lebenswelt, he says:

The world is not an object such that I have in my possession the law of its making; it is the natural setting of, and field for, all my thoughts and all my explicit perceptions. Truth does not 'inhabit' only the 'inner man' or, more accurately, there is no inner man, man is in the world, and only in the world does he know himself. When I return to myself from an excursion into the realm of dogmatic common sense or of science, I find, not a source of intrinsic truth, but a subject destined to the world (Merleau-Ponty, 1945, p.6).

Merleau-Ponty's phenomenological philosophy moves away from Husserl's transcendental phenomenology as used by Jaspers. The former is built as a phenomenology of existentialism, markedly anthropological in this period, taking an ontological turn in the later Merleau-Ponty. Contrary to Husserl, who remains an essentialist to the very last of his works, loyal to the transcendental pursuit of pure conscience by means of phenomenological reduction (Moreira, 2011b, 2012), for MerleauPonty (1945)

The most important lesson which the reduction teaches us is the impossibility of a complete reduction. This is why Husserl is constantly re-examining the possibility of reduction. If we were absolute mind, the reduction would present no problem. But since, on the contrary, we are in the world, since indeed our reflections are carried out in the temporal flux on which we are trying to seize (because they sicheinströmen, as Husserl says), there is no thought which embraces all our thought (p.10).

Insofar as we are in the world, rooted/living in it and building it in tandem, we can never fully depart from it. In this sense, the methodological tool of phenomenological reduction, proposed by Husserl as something capable of completion, seizing pure essence, can never be possible for MerleauPonty because the essence is indeed located in existence. One does not expect to arrive at an understanding of man and the world from any starting point than that of their facticity and culture, aware that man and the world are mutually constructed (Moreira, 2007a, 2009a, 2011b, 2012).

Merleau-Ponty, willing to remain in the level of pre-reflexive thought, advances a phenomenology that exists behind the subject-object dichotomy. For Claude Lefort, the editor of Merleau-Ponty's posthumous book "The Visible and the Invisible [Le visible et I' invisible]" (1964), - a title which singlehandedly evokes thoughts free from the subjectobject categories (Moreira, 2001a, 2007a, 2009a) - Merleau-Ponty's philosophy goes beyond Western dualist thinking and is fueled by cyclical, neverending dialectics. Reality is shallow; no absolute truths exist. The world has multiple dashes, like a painting from Cézanne. Merleau-Ponty (1964) ultimately overmatches the dichotomy between the natural world and the cultural world by prioritizing the Lebenswelt (life-world). Studies completed in the last twenty-five years have shown that one may find in Merleau-Ponty's thought, via the concept of Lebenswelt, a fruitful course to think about clinical phenomenology and phenomenological psychopathology (Bloc \& Moreira, 2013; Chamond, Moreira, Decoq, \& Leroy-Viémon, 2014; Guedes \& Moreira, 2009; Leite \& Moreira, 2009; Moreira, 1993, 1994, 1995, 1997, 1998, 1999, 2000, 2001a, 2001b, 2004, 2007a, 2007b, 2007c, 2009a, 2009b, 2009c, 2010, 2011a, 2011b, 2014; Moreira \& Bloc, 2012a, 2012b; Moreira \& Cavalcante, 2008; Moreira \& Melo, 2008a, 2008b; Moreira et al., 
2010; Moreira, Meneses, Andrade, \& Araujo, 2010; Moreira, Nogueira, \& Rocha, 2007; Moreira, Saboia, Beco, \& Soares, 1995; Pita \& Moreira, 2013; Rocha, Boris, \& Moreira, 2012; Tatossian \& Moreira, 2012; Telles \& Moreira, 2014).

In order to foster a reflection on the methods of phenomenological psychopathology, expanding its possibilities far beyond the traditional use of transcendental phenomenology, which pursues the generality proper to essence, the aim of this article is to show the ambiguous phenomenological method inspired by Merleau-Ponty's philosophy as a feasible alternative for research in psychopathology (as a means of explicitly integrating the world and therefore culture) characterizing the psychopathological phenomenon as an experience of the Lebenswelt, in the intersection between the singular and universal - in the reversibility of the chiasm.

\section{The pursuit of essence in the lived pathology}

In his clinical practice as a psychiatrist, Jaspers claimed that the treatment of mental illness should include more than treating the objective symptom, thus advocating for the inclusion of subjective elements from the patient's experience. It was precisely as an attempt to access these subjective aspects that Jaspers reached for Husserl's early writings. During the first period of Husserl's writings, his main emphasis, from which he will never fully depart, is set upon a methodological question, that is, the pursuit of a phenomenological method capable of reaching things themselves before reflecting upon them; before science and before representation. His goal was to develop a method capable of reaching the essence of the phenomenon, that is to say, a transcendental method.

Starting from the description of the lived psychopathology, Karl Jaspers was searching for its essence in its generality. Jaspers' methodological concern appears more conspicuously in an article approach is a comprehensive method (Jaspers, 1912/2005, 1913/1987). Jaspers' effort expands and evolves to a kind of contemporary psychopathology aiming to describe pathological generality without ever departing from each subject's clinical singularity (Messas, 2008, 2014).

Jaspers' pioneering contribution, insofar as it considered the elements for psychiatry, via the phenomenology of Husserl, lay the groundwork for psychopathology as a field of study (Moreira, 2002). Contrary to medicine and traditional psychiatry, for which the natural attitude of reaching for objective and observable symptoms of the disease is sufficient, Jaspers claimed that mental illnesses cannot be understood and treated uniquely by virtue of biomedical traditions of objective reality, thus proposing phenomenology as a method for reaching subjective aspects. Nevertheless, Jaspers is content with describing his ideas and, as Tatossian points out (1979/2006, p.27), "a topological description does not have the immediacy of phenomenological description. Such a thing is no more the phenomenon which shows itself than its theoretical representation".

Therefore Jaspers - bearing in mind that the phenomenological method advanced by him in psychiatry was the Husserlian transcendental method, which lead him to pursue the essence of mental illnesses -, felt content with simple description. In searching for the essence, he was able to reach for generality, i.e., which is general in every pathology, hence the title of his classic work, "General Psychopathology" (1913/1987). Jaspers' fundamental lasting contribution in contemporary phenomenological psychopathology was the pursuit of essence. According to Moura (2014),

Its aim is to formulate categories, arriving at typical essences, but in as much as they are not bereft of temporal and historical reality: studies in theory must be interlaced with clinical analysis; general dimensions must be recognized in personal history, in which the structure unfolds concretely and temporarily, whilst personal history must anticipate or share certain general conditions, allowing typical forms, which are not limited to them, to emerge (p.15). 


\section{Understanding the Lebenswelt in the lived pathology}

Beginning from Husserl's later thinking, as interpreted by Merleau-Ponty, philosophical phenomenology becomes more than a method, but the possibility of building an independent anthropology (Tatossian \& Giudicelli, 1973), the goal of which becomes the structural unity of possible experiences (Moreira \& Bloc, 2015). Taking experience as the starting and destination point translates into a movement implying a place, which in turn correlates to my 'there is' (incarnate I). That means precisely to know what does movement express, not what is contained in our verbal concept of "movement"; that is, apprehending the movement communicates abundance, or coordinates the body in the world. For Merleau-Ponty (1953/2013), "[the movement] is not interobjective relation, but modality of my relation with the world" (p.88). Yet "the movement is constantly before or after the moment in which I apprehend it" (p.89).

The understanding of experience as movement and expression gives rise, with regard to psychopathology, to the understanding of clinics as something unfinished, ever-starting, wherein one could not possibly apprehend an essence or anything that is general. As Saint-Aubert (2011) points out, the traditional approach to conscience (the one present in Husserl and Jaspers) was connected to a "conception of the sense as essence", clearly distinct from the idea proposed by Merleau-Ponty in his 1953 lectures at the Collège de France. For him, life is a circular movement, and

Circularity is not given as essence, but lived through as a typical modulation of local space, i.e., a nonstop derivation, life as such in simulation of a motion route in the outline. Every second the line changes position, but always in the same way; the line is not fastened to a fixed point in the plane, but comes out as the product of 'a typical activity' assuming the peculiar style of its transformation (Saint-Aubert, 2011, p.17).
The idea of movement as reversibility, present in the later Merleau-Ponty, markedly in his "The world of sense and the world of expression [Le monde sensible et Le monde de l'expression]" (1953/2013) and "The visible and the invisible" (1964), is radicalized by means of an ontology of the sensitive - the intrinsic ambiguity of the Lebenswelt concept that, since pre-reflexive, is neither singular nor universal, neither inner nor outer, neither conscious nor unconscious, and therefore cannot be understood separately; the Lebenswelt is ambiguous, it is the perceptive experience as expression, traversed by contents that slip from thought to sensation, where conscious and unconscious become both extensive dimensions of a single life experience (Moreira, 2012). In other words, consciousness becomes dissolved in the unconscious; it becomes a perceptive consciousness, which (as expressivity) is the movement of reversibility whereupon the singular crosses the universal in the subject-object simultaneity, just as Merleau-Ponty (1964) illustrated in his remarkable example of two hands that, when touching one another, are both subject and object at the same time. That is the chiasm of the Lebenswelt, which consists in the man-world intersection, in the mingling of objective experience with subjective experience.

In clinical terms, it is not the pursuit of reliving experience so as to seize its essence, but of probing into it, into what it is, in order to reach the prereflexive and pre-predicative plane from which it emerges. To arrive at this point is to land at what Husserl called lived-life (Lebenswelt) (Moreira \& Bloc, 2015; Tatossian \& Giudicelli, 1973). According to Merleau-Ponty (1945)

To 'understand' is to take in the total intention - not only what these things are for representation (the 'properties' of the things perceived, the mass of 'historical facts', the 'ideas' introduced by the doctrines) -, but the unique mode of existing expressed in the properties of the pebble, the glass or the piece of wax, in all the events of a revolution, in all the thoughts of a philosopher (p.17). 
To pursue an understanding of the Lebenswelt in the lived psychopathology is therefore to try to reach for the meanings of lived experience in its totality, which is not purely objective or subjective, singular or universal, conscious or unconscious. The Lebenswelt is the slice of worldly existence of an individual, in its uniqueness.

When coming to the incarnate subjectivity of the human body, which I continue to refer to as the Lebenswelt, I must find something that is not 'psychic' in the sense of psychology (that is, a Gegenabstraktion to the Nature of blosse Sachen), I must reach an intersubjectivity, a universe of Geistthat, if not be a second nature, nonetheless has its solidity and completeness still in the mode of the Lebenswelt - that is, I must also, across the objectifications of linguistics, of logic, rediscover the Lebenswelt logos (Merleau-Ponty, 1964, p.165).

According to Tatossian (1979/2006), the attempt to understand the Lebenswelt means to redirect clinics to the primary reality of the lived psychopathology. The world of signification is, as it appears to us, the world of individuals, existence lived in its unicity (Tatossian \& Moreira, 2012). It is the place wherein the individual lives before reflecting upon on that which is lived, be it familiar with a world that is 'his', thereby rejecting not only the extreme particularity, but also the extreme generality of experience. There is always a world of daily life, taken as reality, but one that is epitomized by social, cultural, political and historical planes amounting to common meaning, irrespective of the particular content (Moreira \& Bloc, 2015).

For Tatossian, the Lebenswelt is the world correlative to the natural attitude at the level of pre-intentionality, that is to say, an experience that may vary in content as Lebenswelten, but "the form of the Lebenswelt is a single one" (p.88), as there is always a 'common sense', insofar as "'my' world must always be 'our world', i.e., a world of intersubjectivity, a world of daily life" (1979/2006, p.88). Such a world exists under, that is, behind, the constructions of thought (Moreira \& Bloc, 2015), underscoring the double effort of psychopathology to address two experiences of the patient's Lebenswelt: on the one hand, the pre-theoretical and pre-objective experience, happening before the subject; on the other, the questioning of how one's own particular Lebenswelt - putting its imprint into our experience, our life and ways of appearing -, is made. Whence the pursuit, a common goal, of understanding how the patient constructs his self and the world, considering at all times his own relationship with his body and the path of natural evidence (usually a failure for the patient) (Moreira $\&$ Bloc, 2015). This seems to be the struggle of ambiguous clinical phenomenology that, while striving for the development of phenomenological knowledge in psychopathology, puts this knowledge, about the pathological modus operandi to reach for the patient's Lebenswelt in its singularity, in brackets. This understanding is thus given in the patient-illness-clinics-world experience, in the circular movement of the chiasm that distinguishes the Lebenswelt from the psychopathological experience.

Tatossian (1979/2006) reminds us how difficult it is for clinical practice to be implemented, as it has little to do with liberating phenomenological experience itself from the objective and subjective movements intertwined in the experience of the Lebenswelt. Still, it is imperative to reach for the patient's experience by means of his own presentations of his self - not putting ourselves in his place and skin or soul in an outmoded intropathy (Einfühlung), but rather as Binswanger (1960/2005, 1965/2010) described hermeneutic communication or redoubled communication (Moreira \& Bloc, 2015).

Trying to reach the Lebenswelt of the psychopathological experience - understood as a movement of constant reversibility between the patient, illness, clinician and the world -, is arduous due to the inseparability between the objective and the subjective experience, as well as due to the difficulty of placing in its center on the phenomenon that shows itself from the experience of the other. Such methodological questions its own constitution and the world's, springing at the same time and always from the experience that is clinically shown in the chiasm (Moreira \& Bloc, 2015). For Tatossian (1979/2006), the Lebenswelt "exists as the concrete 
world of daily life, individual, 'my' world, also being 'our' world because it is rooted in historicity and intersubjectivity" (p.207), thereby rising above dichotomous understanding and assuming an ambiguous means of understanding psychopathological experience, one which encompasses the constitution of subjectivity that is not merely individual, for it is part of a world simultaneously constructed by the subject and others in its distinctive intersubjective-objective character: as flesh, in the chiasm. I may then recognize a framework of psychopathology from a common a priori that allows me to recognize it as thus.

In other words, I may only recognize a patient in a framework of depression by means of a prior knowledge of what depression is; something made possible by a natural attitude built in the Lebenswelt. On the other hand, this attitude is not possible to me but by means of an experience that is shown and clinically presented, thus allowing, from the contact with the other, the recognition of a modus operandi that gets close to that which is depressively lived (Moreira \& Bloc, 2015, p.10).

Whereas one can interpret the prioritization of the phenomenon as a comprehensive way of the subject's being, it does not however subsist solely as a particular thing: there are common elements that permit us to recognize this way of being. I'm talking about an existential style that characterizes a specific psychopathological functioning (Moreira \& Chamond, 2012). Tatossian (1979/2006, 1994) does not randomly refer to diagnostics "of depressivity and schizophrenicity", but rather "of depression and schizophrenia". He incorporates, in this manner of speaking, the movement coming from the Lebenswelt, perception as movement and expression, existing empirically and aprioristically with and in the symptom. Here we can connect clinical practice, recognized and developed through the contact with the patient and psychopathology, as a field whose goal is to understand the different pathological modus operandi, grounded on the foundations of clinical practice, and hence moving from a natural attitude to a phenomenological one, allowing the phenomenon to unveil. Likewise, when the clinician is with his patient, he is with him and with his pathology, in a circular, reversible, constant moving experience consisting of subject-subjectobject-world. I am defending, alongside Tatossian, a psychopathology derived from and for clinical practice. It is in this sense indeed that we may speak of Lebenswelt practice (Tatossian \& Moreira, 2012).

\section{Conclusion}

The aim of the present study is to expand on the phenomenological method in psychopathology from the pursuit of essence developed by Karl Jaspers to the comprehension of the Lebenswelt in the lived psychopathology. Having set the essences aside and headed for the Lebenswelt of the lived psychopathology, the ambiguous phenomenological method assumes the understanding that the lived pathology emerges from the chiasm, from the man-world intersection in its reversibility, which is not something "inner" or "individual". Culture, as a world dimension, does not only influence life, but is a constitutive part of it. In a significant era in which, despite all progress in psychiatry and clinical psychology, mental illnesses are coming to the forefront of attention in terms of their prevalence. It is imperative to think this phenomenon in regard to the world of history, politics and culture (besides biology and psychology) as a constitutive horizon of the phenomenon of falling ill.

This article is an invitation to reflect upon the methodological issues of phenomenological psychopathology so as to mutually pave the multiple ways that intersect its universality, or what is common to many kinds of phenomenology - and singularity -, or, what is specific to each one of them. It is important to point out that these are different methods, striving to advance the study of phenomenological psychopathology, in a way that one is not "better" than the other, but different, all of them being phenomenological. Taking into consideration the many viewpoints in its methodological implications, thus expanding these methods, might be an interesting proposition 
for the development of phenomenological psychopathology as a field of study.

More than essence (or what is general), this methodological proposition in psychopathology aims to delve into experience itself, before it is reflected upon - the Lebenswelt. The Lebenswelt practice learns from experience.

\section{References}

Bidney, D. (1989). Phenomenological method and the anthropological science of the cultural-life. In M. Natanson. Phenomenology and the social sciences. Evanston: Northwestern University Press.

Binswanger, L. (2005). Melancolie et manie. Paris: Presses Universitaires de France. (Publié à l'origine en 1960).

Binswanger, L. (2010). Délire. Grenoble: Jérôme Millon. (Publié à l'origine en 1965).

Bloc, L. G., \& Moreira, V. (2013). Sintoma e fenômeno na psicopatologia fenomenológica de Arthur Tatossian. Revista Latinoamericana de Psicopatologia Fundamental, 16(1), 812-824.

Chamond, J., Moreira, V., Decoq, F., \& Leroy-Viémon, B. (2014). La dénaturation carcérale. Pour une psychophénomenologie du corps en prison. L'information Psychiatrique, 90, 673-682.

Guedes, D. D., \& Moreira, V. (2009). El método fenomenológico crítico con base en el pensamiento de Merleau-Ponty. Terapia Psicológica, 27(2), 247-257.

Husserl, E. (1970). The crisis of European sciences and transcendental phenomenology. Evanston: Northwestern University Press. (Original work published 1936).

Jaspers, K. (1987). Psicopatologia geral. Rio de Janeiro: Atheneu (Originalmente publicado em 1913).

Jaspers, K. (2005). A abordagem fenomenológica em psicopatologia. Revista Latinoamericana de Psicopatologia Fundamental, 8(4), 769-787. (Originalmente publicado em 1912).

Leite, E., \& Moreira, V. (2009). A contribuição de Tellenbach e Tatossian para uma compreensão fenomenológica da depressão. Arquivos Brasileiros de Psicologia, 61(3), 46-56.

Merleau-Ponty, M. (1945). Phénoménologie de la perception. Paris: Gallimard.

Merleau-Ponty, M. (1964). Le visible et l'invisible. Paris: Gallimard.

Merleau-Ponty, M. (2013). Le monde sensible et le monde de l'expression. In M. Merleau-Ponty. Résumés de cours. Collége de France 1952-1960. Paris: Gallimard. (Publié à l'origine en 1953).

Messas, G. (2008). Psicopatologia fenomenológica contemporânea. São Paulo: Roca.
Messas, G. (2014). Psicose e embriaguez. Psicopatologia fenomenológica da temporalidade. São Paulo: Intermeios.

Moran, D., \& Mooney, T. (2002). The phenomenology reader. London: Routledge.

Moreira, V. (1993). Psicoterapia centrada na pessoa e fenomenologia. Psicologia: Teoria e Pesquisa, 9(1), 157-172.

Moreira, V. (1994). Para além da pessoa: o conceito de carne de Merleau-Ponty. Arquivos Brasileiros de Psicologia, 46(1/2), 186-203.

Moreira, V. (1995). A fenomenologia como articulação entre teoria e prática. Insight, 48, 12-14.

Moreira, V. (1997). Supervisionen psicoterapia: Un enfoque fenomenologico-existencial. Terapia Psicológica, 4(28), 93-99.

Moreira, V. (1998). Una comprensión de la psicopatología desde la fenomenología de Merleau-Ponty. Revista Chilena de Psicologia, 19(1), 106-112.

Moreira, V. (1999). Modos de constitución de la subjetividad: Una perspectiva fenomenológica transcultural. Psykhe (Santiago), 8(1), 27-31.

Moreira, V. (2000). Ideologia e psicopatologia: uma discussão fenomenológica transcultural. Revista Latinoamericana de Psicopatologia Fundamental, 3(4), 80-91.

Moreira, V. (2001a). Mas allá de la persona: Hacia una psicoterapia fenomenologica mundana. Santiago: Editorial Universidad de Santiago de Chile.

Moreira, V. (2001b). Psicopatologia, fenomenologia e cultura: a contribuição de Arthur Tatossian. Revista Latinoamericana de Psicopatologia Fundamental, 4(3), 127-130.

Moreira, V. (2002). Parte II. In V. Moreira \& T. Sloan. Personalidade, ideologia e psicopatologia crítica. São Paulo: Escuta.

Moreira, V. (2004). O método fenomenológico de Merleau-Ponty como ferramenta crítica na pesquisa em psicopatologia. Psicologia: Reflexão e Crítica, 17(3), 447-456.

Moreira, V. (2007a). De Carl Rogers a Merleau-Ponty: a pessoa mundana em psicoterapia. São Paulo: Annablume.

Moreira, V. (2007b). Critical phenomenology of depression in Brazil, Chile and the United States. Latin American Journal of Fundamental Psychopathology On Line, 4(2), 193-218.

Moreira, V. (2007c). Significados posibles de la depresión en el mundo contemporaneo: Una lectura fenomenológica mundana. Psykhe (Santiago), 16(2), 129-137.

Moreira, V. (2009a). Clínica humanista-fenomenológica: estudos em psicoterapia e psicopatologia crítica. São Paulo: Annablume.

Moreira, V. (2009b). A Gestalt-terapia e a abordagem centrada na pessoa são enfoques fenomenológicos? Revista da Abordagem Gestáltica, 15(1), 3-12. 
Moreira, V. (2009c). Da empatia à compreensão do Lebenswelt na psicoterapia humanista-fenomenológica. Revista Latinoamericana de Psicopatologia Fundamental, 12(1), 59-70.

Moreira, V. (2010). Possíveis contribuições de Husserl e Heidegger para a clínica fenomenológica. Psicologia em Estudo, 15(4), 723-731.

Moreira, V. (2011a). O inconsciente no pensamento de Merleau-Ponty: contribuição para a psicoterapia. Revista Latinoamericana de Psicopatologia Fundamental, 14(1), 110-121.

Moreira, V. (2011b). A contribuição de Jaspers, Binswanger, Boss, e Tatossian para a psicopatologia fenomenológica. Revista da Abordagem Gestáltica, 17(2), 172-184.

Moreira, V. (2012). Parte II. In A. Tatossian \& V. Moreira. Clínica do Lebenswelt. São Paulo: Escuta.

Moreira, V. (2014). Merleau-Ponty and the experience of anxiety in humanistic phenomenological psychotherapy. Self \& Society: An International Journal of Humanistic Psychology, 41(3), 75-81.

Moreira, V., \& Bloc, L. (2012a). Clínica do Lebenswelt (mundo vivido): articulação e implicação entre teoria e prática. In A. Tatossian \& V. Moreira. Clínica do Lebenswelt (mundo vivido): psicopatologia e psicoterapia fenomenológica (pp.285-298). São Paulo: Escuta.

Moreira, V., \& Bloc, L. (2012b). Fenomenologia do tempo vivido no transtorno bipolar. Psicologia: Teoria e Pesquisa, 28(4), 17-24.

Moreira, V., \& Bloc, L. (2015). O Lebenswelt como fundamento da psicopatologia fenomenológica de Arthur Tatossian. Psicopatologia Fenomenológica Contemporânea, 4(1), 1-14.

Moreira, V., \& Cavalcante, F. S. (2008). O método fenomenológico mundano na pesquisa em psico(pato)logia e a contribuição da etnografia. Estudos e Pesquisas em Psicologia (UERJ), 8(2), 245-260.

Moreira, V., \& Chamond, J. (2012). O estilo existencial obsessivo compulsivo: Laura prisioneira de sua temporalidade. In A. Tatossian \& V. Moreira (Eds.), Clínica do Lebenswelt. Psicoterapia e psicopatologia fenomenológica (Vol. 1, 16, pp.277-284). São Paulo: Escuta.

Moreira, V., \& Melo, A. K. (2008a). "Minha doença é invisível!". Revisitando o estigma de ser doente mental. Interação em Psicologia, 12(2), 307-314.

Moreira, V., \& Melo, A. K. (2008b). Fenomenologia da queixa depressiva em adolescentes. Aletheia, 27, 51-64.

Moreira, V., \& Sloan, T. (2002). Personalidade, ideologia e psicopatologia crítica. São Paulo: Escuta.

Moreira, V., Melo, A. K., Bloc, L. G., Telles, T. C. B., Araújo, T. C. B. C., \& Evangelista, K. T. (2010). Fenomenologia do estigma em HIV/AIDS e na doença mental. Latin American Journal of Fundamental Psychopathology On Line, 7(1), 45-74.
Moreira, V., Meneses, A. M., Andrade, D., \& Araújo, M. C. S. (2010). Fenomenologia do estigma em HIV/AIDS: "co-estigma". Mental, 8(14), 115-132.

Moreira, V., Nogueira, F. N. N., \& Rocha, M. A. S. (2007). Leitura fenomenológica mundana do adoecer em pacientes do serviço de fisioterapia do núcleo de atenção médica integrada, Universidade De Fortaleza. Estudos de Psicologia (Campinas), 24(2), 191-203. http://dx.doi.org/10.1590/S0103-166X20070 00200006

Moreira, V., Saboia, A., Beco, L., \& Soares, S. (1995). Psicoterapia fenomenológico-existencial: aspectos teóricos de la práctica clinica con base en las competencias. Psykhe (Santiago), 4(2), 121-129.

Moura, A. (2014). Prefácio: entre estrutura e existência. In G. Messas. Psicose e embriaguez. Psicopatologia fenomenológica da temporalidade. São Paulo: Intermeios.

Pita, J., \& Moreira, V. (2013). As fases do pensamento fenomenológico de Ludwig Binswanger. Revista Psicologia em Estudo, 18(4), 689-697.

Rocha, M. A. S., Boris, G. D. J. B., \& Moreira, V. (2012). A experiência suicida em uma perspectiva humanista-fenomenológica. Revista da Abordagem Gestáltica, 18(1), 69-78.

Saint-Aubert, E. (2011). Conscience et expression: avantpropos. In Merleau-Ponty, M. Le monde sensible et le monde de l'expression. Genève: MétisPresses.

Tatossian, A. (1994). La subjectivité. In D. Widlöcher. Traité de Psychopathologie (pp.253-318). Paris: Presses Universitaires de France.

Tatossian, A. (1997). Pratique psychiatrique et phenomenologie. In A. Tatossian. Psychiatrie phénomenologique (pp.179-183). Paris: Acanthe. (Publié à l'origine en 1985).

Tatossian, A. (2006). A fenomenologia das psicoses. São Paulo: Escuta. (Originalmente publicado em 1979).

Tatossian, A., \& Giudicelli, S. (1973). De la phénoménologie de Jaspers au "retour a Husserl": L'anthropologie compréhensive de Zutt et Kulenkampff. Confrontations Psychiatriques, 11, 127-161.

Tatossian, A., \& Moreira, V. (2012). Clínica do Lebenswelt (mundo vivido): psicopatologia e psicoterapia fenomenológica. São Paulo: Escuta.

Tatossian, J., \& Samuelian, J. C. (2006). Posfácio da segunda edição francesa. In A. Tatossian. Fenomenologia das psicoses (pp.347-357). São Paulo: Escuta. (Originalmente publicado em 1979).

Telles, T. C. B., \& Moreira, V. (2014). A lente da fenomenologia de Merleau-Ponty para a psicopatologia cultural. Psicologia: Teoria e Pesquisa, 30(2), 205-211.

Received: February 17, 2016

Final version: March 30, 2016

Approved: April 1, 2016 
